\title{
RESPONSES OF NORMAL SUBJECTS AND OF PATIENTS WITH DIABETES INSIPIDUS TO WATER AND SALT INGESTION ${ }^{1}$
}

\author{
By H. L. WHITE AND THOMAS FINDLEY, JR. \\ (From the Departments of Physiology and of Medicine, Washington University School of \\ Medicine, St. Louis)
}

(Received for publication March 10, 1939)

This paper reports a comparison between normal subjects and patients with diabetes insipidus of some blood and urine responses to the ingestion of water and of hypertonic salt solution, both with and without pitressin. One aspect of this work, the responses of normal and diabetes insipidus subjects to water without pitressin, has already been reported (1). Since the earlier work showed failure of the human diabetes insipidus subject to respond to water ingestion with an acute increase in urine volume, one purpose of the present work is to determine whether such subjects show a corresponding failure, as compared with the normal, of responses as regards salt. Ability to conserve salt when on a low salt intake has also been studied. There has further been a comparison of the acute responses to salt ingestion while on an unrestricted and on a low salt intake.

\section{METHODS}

The usual procedure has been to get several consecutive 20 or 30 -minute urine collections, with 1 or 2 blood samples during this control period. The subject then drank water or salt solution, urine and blood collections being continued. In the experiments with pitressin, a dose of 0.15 unit per kilo subcutaneously was given at the end of the control period, 1 hour before the water or salt ingestion. Experiments were usually begun early in the morning, after a light breakfast or none; no food was taken during the experiments. Urine chlorides were done by a modified Volhard-Harvey titration (2). Serum protein nitrogen was determined by a micro-Kjeldahl method, serum chlorides by Sendroy's titrimetric method (3); in many cases serum viscosity as an index of protein and conductivity as an index of chlorides also were determined as previously described (4), with good agreement with the chemical findings.

\footnotetext{
1 Aided by a grant from the Commonwealth Fund to H. L. White.
}

\section{RESULTS}

The acute responses to water ingestion without pitressin by the normal and the diabetes insipidus subject have already been reported (1); the patient with diabetes insipidus differs from the normal in that no acute increase in urine volume occurs. This finding has also been obtained in 6 additional experiments on 2 more cases seen since the first paper; it occurs whether the subject is on unrestricted (average of 10 grams $\mathrm{NaCl}$ daily) or on low ( 1 gram $\mathrm{NaCl}$ or less daily) salt intake.

When a normal subject drinks 1200 to $1500 \mathrm{cc}$. of water one hour after receiving 0.15 unit of pitressin per kilo subcutaneously, there is a fall of 12 to $21 \mathrm{mgm}$. per cent in serum $\mathrm{NaCl}$, of about 0.1 gram per cent in serum protein, and no consistent change in rate of chloride output or in urine volume (Figure 1). There have been 7 such experiments on 3 normal subjects. In 2 experiments the rates of chloride output and urine volume have shown the progressive fall seen in control experiments where nothing was given to the subject for several hours except small amounts of water.

When this procedure is carried out on the subject with diabetes insipidus the results are the same as with the normal, except, of course, that urine volume is greatly decreased below its initial level by the pitressin, while in the normal it is unchanged. In neither the normal nor the diabetes insipidus subject is serum chloride or rate of chloride output consistently changed by pitressin; in both the normal and the diabetes insipidus subject the course of the serum chloride and of the rate of renal output of chloride following the ingestion of water is the same with pitressin as without. Figure 2 shows an observation on a subject with diabetes insipidus; there are 8 such observations on 3 cases. If the subject has been for some time on an unrestricted salt intake the 
initial rate of output may be 3 to $12 \mathrm{mgm}$. of $\mathrm{NaCl}$ per minute, while on low intake it may be only a few tenths of a milligram per minute. In either case the rate of output is not consistently changed by pitressin or by water ingestion 1 hour later.

When a normal subject on unrestricted salt intake takes 0.25 gram of $\mathrm{NaCl}$ per kilo of body weight in 10 per cent solution, one sees a rise in serum $\mathrm{NaCl}$ of from 40 to $60 \mathrm{mgm}$. per cent, a fall in serum protein of from 0.32 to 0.50 gram per cent, and an increase of 200 to 600 per cent in rate of chloride output within the next few hours (Figure 3). When the subject has been on a low salt intake ( 1 gram daily) for a week to 10 days preceding the experiment, the same results are obtained, except that the percentage increase in rate of chloride output is greater. Thus, in the first condition, the output rises from 3 to $12 \mathrm{mgm}$. of $\mathrm{NaCl}$ per minute to 10 to $30 \mathrm{mgm}$. per minute, while in the second case it rises from 0.3 to $0.6 \mathrm{mgm}$. per minute to 5 to $15 \mathrm{mgm}$. per minute.
The fall in serum $\mathrm{NaCl}$ is only slight after a 10day period of low salt intake following unrestricted intake, e.g., fall from 626 to $618 \mathrm{mgm}$. per cent, in a subject able to conserve salt, i.e., one whose renal $\mathrm{NaCl}$ output will fall to 0.4 to 0.8 gram daily on a daily intake of 1 gram. Since such a subject is not significantly depleted of salt by such a period of low salt intake, he responds to a large dose of salt in essentially the normal fashion, although the absolute rate of salt output following a given dose is usually less than when such dose is given during a period of unrestricted intake. The total time required for the elimination of such a dose is usually 4 or 5 days when on a daily low salt intake as compared with 3 or 4 days when on unrestricted intake.

In the normal subject, the increase in rate of salt output following such a dose begins in the third or fourth half hour. Many experiments have been carried out in which the urinary response to various doses of $\mathrm{NaCl}$ in 10 per cent solution has been followed in 6 normal subjects on unrestricted
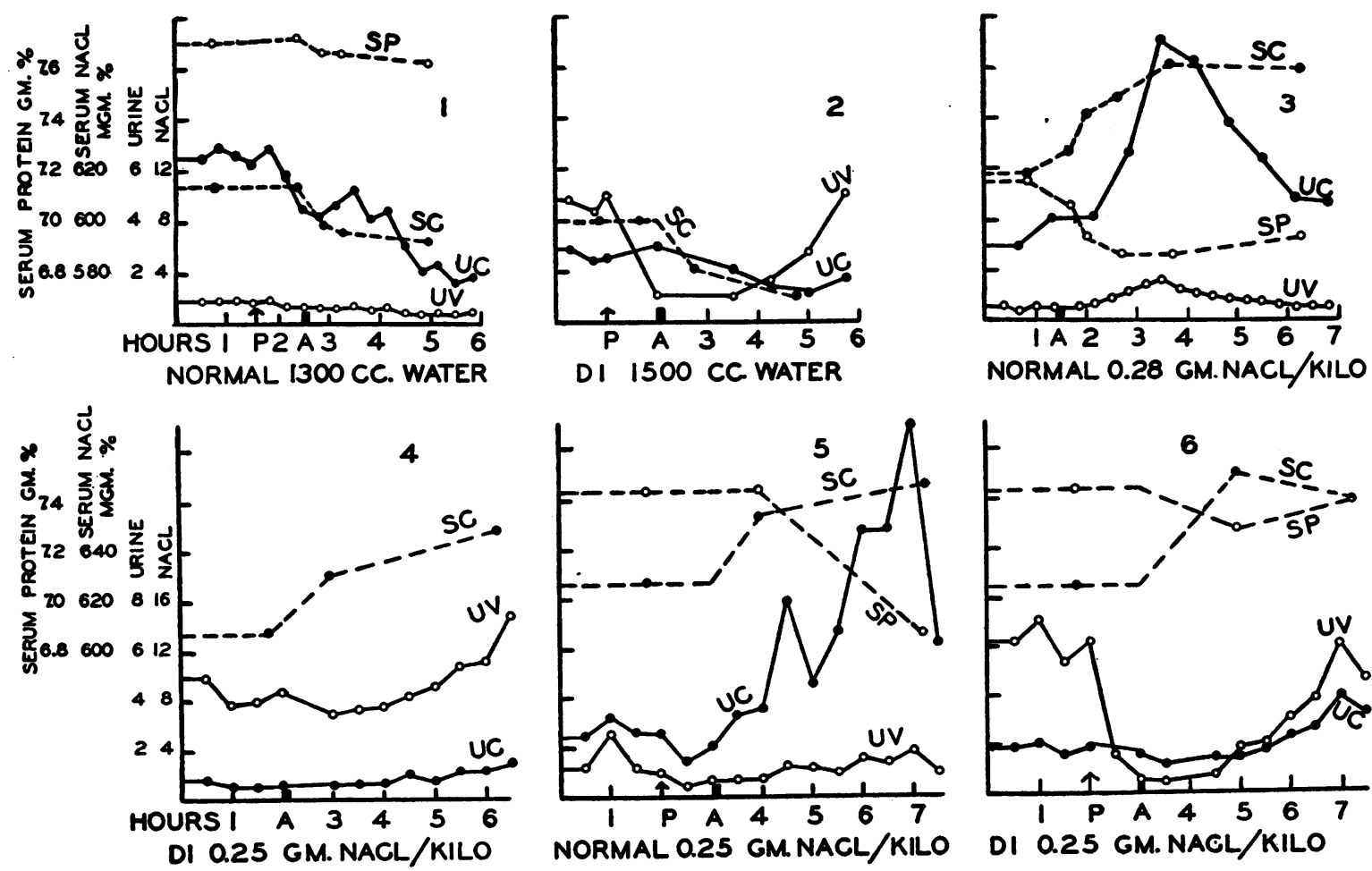

FIGS. 1 to 6. At $A$ the subject drank the material designated under each figure; at $P$ 0.15 unit of pitressin per kilo was administered subcutaneously. Urine designates urine volume (UV) in cc. per minute; $\mathrm{NaCl}$ designates renal output of $\mathrm{NaCl}$ in mgm. per minute (UC); Serum $\mathrm{NaCl}$ designates level of serum $\mathrm{NaCl}$ in mgm. per $100 \mathrm{cc}$. (SC); Serum protein designates serum protein in grams per 100.cc. (SP). DI = Diabetes insipidus. 
daily salt intake ( 7 to 14 grams daily). It was found in control experiments, where the subjects took nothing except occasional small drinks of water, that the rate of chloride output usually falls during the day, as from 6 to $12 \mathrm{mgm}$. per minute in the morning to 2 to $5 \mathrm{mgm}$. per minute in the afternoon. If, then, after 6 half-hourly urine collections beginning at 8 a.m. a dose of salt is taken and the collections continued for several hours more with the result that the rate of salt output rises during the afternoon, this rise may safely be ascribed to the salt ingestion. Many such experiments have led us to conclude that with a dose of 0.17 gram of $\mathrm{NaCl}$ per kilo the rate of chloride output usually shows an increase of 50 to 100 per cent, beginning in the fourth or fifth half hour; in the remaining cases the rate at least stays constant, i.e., the effect of the salt dose is seen in that the fall of control experiments does not occur. This is about the threshold dose which can safely be predicted to show an appreciable acute effect on rate of chloride output. With 0.22 gram of $\mathrm{NaCl}$ per kilo some increase in rate of output has always been seen; this is also true with 0.25 and 0.31 gram per kilo, the magnitude of the effect being in general proportional to the dose. Also, the larger the dose the sooner is the increase in output manifest; thus, with 0.31 gram per kilo it is seen in the third half hour.

When a subject with diabetes insipidus on unrestricted salt intake took 0.25 gram of $\mathrm{NaCl}$ per kilo, there was usually no increase in rate of chloride output within the next 5 hours in 3 of the 4 cases studied (Figure 4); 2 of these cases were also studied during a period of low salt intake with the same result. This is not due to a failure of absorption of the salt, since the serum chloride rose as much in these cases as in the normal subjects. One of these cases was the most severe of the 4, a 10-year-old girl weighing 25 kilos with a daily urine output of 9 to 10 liters on 3.3 grams daily salt intake and of 6 liters on 0.8 gram daily (subject of Figure 4). In 1 other case the urinary chloride response has not been essentially different from the normal, either on unrestricted or on low salt intake; this was a relatively mild case, an adult with a daily urine output of 4 to 5 liters. Various observers $(5,6$, $7,8,9,10,11,12,13)$ have reported that chloride elimination may be delayed in diabetes insipidus but in only a few cases has the blood been followed or the urine course of the first few hours observed.

The longer time relations of the urinary responses to such a salt dose may be compared in the normal and the diabetes insipidus subject. We have found no significant difference; in both, the excess salt is eliminated in 3 to 4 days when on an unrestricted salt intake and in 4 to 5 days when on low salt intake. We confirm Veil's statement (14) that in normal subjects following a dose of about 0.25 gram of $\mathrm{NaCl}$ per kilo the serum chloride is up for the first 24 hours only, being back to normal at the end of 24 hours and thereafter. We do not confirm his finding that the chloride output is up for the first 24 hours, back to normal for the second 24 hours, and then up again for the third day, during which the remainder of the dose is eliminated. We find rather that the output for the second 24 hours is almost as great as for the first; it then falls during the third and fourth days, at the end of which the dose has been essentially completely eliminated. The striking finding is that during the second 24 hours the output is about as high as during the first 24 hours, although the serum chloride is usually back to normal and sometimes lower. This is true for both the normal and the diabetes insipidus subject. It is also true when the subjects are on low (except for the dose) daily salt intake, the only difference here being that a day more may be required for the dose to be eliminated. A series of observations is shown in Figures 7 to 10.

The stimulus for the maintained increase in output after serum chloride has returned to normal may be an increase in plasma volume, although the mechanism through which this might operate is not clear. Our only clue as to such changes in plasma volume is the plasma protein level; this usually but not always is below normal while the excess salt is being eliminated. Even in the cases where plasma protein returns to normal before elimination of the salt dose is completed, it may be that plasma volume remains above normal. Within 2 or 3 days diluted plasma protein may be built up to normal by new protein formation even though it is probably safe to regard acute (measured in hours instead of days) falls in plasma protein as indicating increases in plasma volume.

Another interpretation of the maintained increase in salt output after serum chloride has re- 


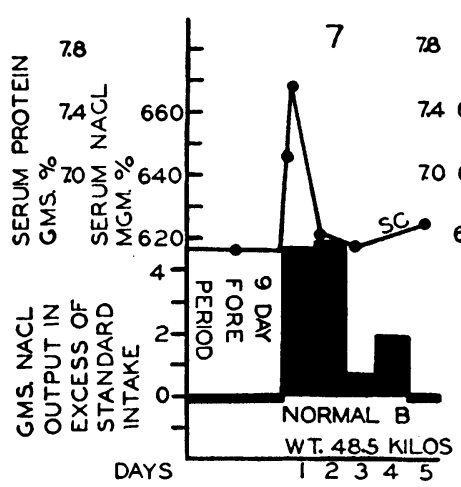

GMSNACL INTAKE $4 \quad 164444$

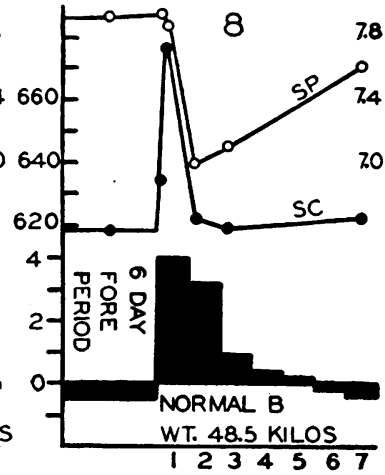

113111111

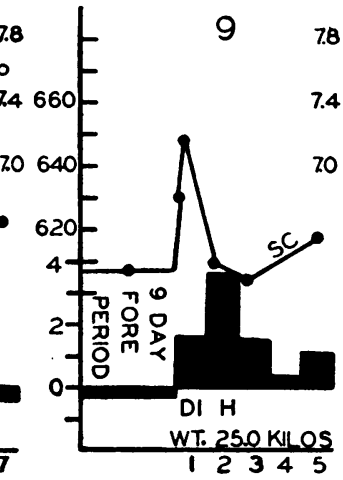

33.2533333333

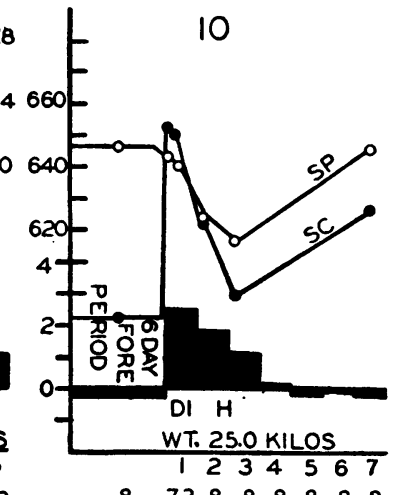

$\begin{array}{lllll}.8 & 7.3 .8 & .8 .8 & .8 .8\end{array}$

FIgs. 7 to 10. The solid blocks show the amount of $\mathrm{NaCl}$ put out in the urine in excess (or deficit) of the standard intake, where standard intake is the daily intake other than the experimental dose. Thus, in Figure 7, the intake in the food was 4 grams daily but on Day 1 there was an additional dose of 12 grams. The sum of the blocks above the zero line adds up to the dose by the time chloride equilibrium is reattained. At equilibrium, daily renal output of $\mathrm{NaCl}$ is a few tenths of a gram less than daily intake, as is seen in the foreperiod.

turned to normal is that those elements of the tubular epithelium responsible for chloride reabsorption may, after having once attained salt equilibrium at a higher level, become desalted only slowly even in the presence of an environmental fluid which is again normal with respect to salt; so long as these elements are more than normally salty they will fail to reabsorb salt to the normal degree of completion. The principle is analogous to that in which respiration is believed to be regulated by the state of the interior of the respiratory center cells or peripheral chemoreceptors rather than by the state of the blood per se. Whatever be the interpretation, one must believe that the factors regulating salt reabsorption by the tubules are represented by some stimulus acting in or on the tubular cells themselves; it is inconceivable that these cells can be apprised of the existence of salt stores at some distant point in the body except through the operation of some process acting upon them immediately. The acute rise in salt output occurring in normal and in some diabetes insipidus subjects following a large dose of salt is logically explained as due to the accompanying acute rise in plasma salt. The failure of some subjects with diabetes insipidus to show such increase in output in spite of the usual rise in serum chloride may be "explained" by the statement that the tubular cells of such subjects are slower to respond to environmental changes than the normal individual. The maintenance of an increased salt output in both the normal and the diabetes insipidus subject after the serum chloride has returned to or below normal and the cessation of an increased salt output without further demonstrable change in serum chloride level, when the excess has been eliminated, demands some more subtle mechanism.

When a normal subject takes 0.25 gram of $\mathrm{NaCl}$ per kilo 1 hour after 0.15 unit of pitressin per kilo subcutaneously the increases in serum chloride and in chloride output are the same or somewhat less than without pitressin. Four such experiments have been done on 3 normal subjects. Where the rise in serum chloride and in chloride output is less than without pitressin the diminution in effect is presumably due to interference by the pitressin with intestinal absorption. There has been no evidence that pitressin accelerates the elimination of such a dose of salt under our experimental conditions. A typical experiment is shown in Figure 5.

When a subject with diabetes insipidus takes 0.25 gram of $\mathrm{NaCl}$ per kilo in 10 per cent solution 1 hour after 0.15 unit of pitressin per kilo subcutaneously we find, as in the normal, that the course is not greatly changed by the pitressin; the rise in serum chloride and in chloride output is the same or somewhat less than without pitressin. Three such experiments have been done on 2 with diabetes insipidus; one is shown in Figure 6 (same subject as in Figure 4). In several other experiments, where the blood was not studied, carried out on another diabetes insipidus subject who failed to show within 5 hours any increase in 
chloride output following such a dose of salt without pitressin, there was still no increase in output following the salt when pitressin was given, i.e., the addition of pitressin did not render normal the response of these subjects to the salt dose.

Some incidental observations may be noted. One is that in the 2 diabetes insipidus cases adequately observed, there have been greater spontaneous fluctuations, on constant diet, in the serum chloride level than is usually seen in normal subjects. Thus, 1 subject showed within a week high and low values of 631 and $592 \mathrm{mgm}$. of $\mathrm{NaCl}$ per 100 cc., respectively; another showed conductivity readings indicating a spread of $41 \mathrm{mgm}$. per cent. This increased lability of the serum chloride level in diabetes insipidus has also been noted by Marx (15). There has been no correlation between daily variations in serum chloride level and in urine output. One of us (H. L. W.) has observed correspondingly large spontaneous fluctuations in serum chloride level in dogs with experimental diabetes insipidus on constant diet, also without correlation with daily urine output. In our experience, normal subjects (either human or $\operatorname{dog}$ ) do not show changes in serum chloride as great as $40 \mathrm{mgm}$. per cent even when there are large changes in chloride intake. Thus, a normal child showed within a 5 -week period serum $\mathrm{NaCl}$ values of $616,626,618$, and $622 \mathrm{mgm}$. per cent; the first 2 values were obtained during a period of relatively high ( 4 grams daily) salt intake, the second 2 values during a period of low (1.0 gram daily) intake.

The finding that a large drink of water when preceded or accompanied by pitressin dilutes the serum chloride to as great an extent as it does without pitressin, with no increase in amount of urinary chloride output, speaks against the view that pitressin "mobilizes" chloride from tissues into blood. We also fail to find any consistent increase in chloride output or in serum chloride following pitressin unaccompanied by a drink of water.

\section{DISCUSSION}

The views expressed here are at variance with those of various German workers. For example, Veil $(13,16)$ emphasizes the classification of diabetes insipidus into 2 types, the hyperchloremic-hypochloruric and the hypochloremic-hyper- chloruric. A partial summary of Veil's views is attempted in the following paragraph.

If a hyperchloremic-hypochloruric case is given 10 to 20 grams of $\mathrm{NaCl}$, his plasma protein does not dilute, as does the normal; rather, it may increase. This means that no water is drawn into the blood and indicates a reduction of the water depots. Since it occurs with normal water content of the blood, it must mean a disturbance of the exchange processes between blood and tissues. Such a case also shows a much greater rise of serum chloride to a given dose of salt than does the normal; the ability of the tissues to take up salt is diminished. In the normal the salt passes from the blood into the tissues as well as into the urine; in diabetes insipidus it fails to enter the tissues. The high molecular concentration of the blood so produced stimulates the kidneys to increased water elimination. Such subjects are much more sensitive to water deprivation than the normal; their plasma protein rises much more on deprivation. This is not true with primary polydipsia or with hypochloremic-hyperchloruric diabetes insipidus. The subject with hyperchloremic diabetes inspidus always shows a retarded elimination of chloride; this is not due to any altered behavior of the kidneys but to a disturbance of the blood-tissue salt exchange. Pituitrin acts on the tissues in general, not on the kidneys, restoring to normal the tissues' ability to hold salt. It therefore has an antidiuretic action on the hyperchloremic but not the hypochloremic type of diabetes insipidus because the latter type already shows normal ability of the tissues to hold salt.

The evidence for the statements in the preceding paragraph is scattered through a number of publications and, in our opinion, is not always adequate. First, as to the idea that the hyperchloremic type of diabetes insipidus is merely a disturbance of exchange between tissues and blood, the fact that the blood salt rises on salt administration without corresponding rise in renal salt output shows that the kidneys are not responding normally. Second, it is not true, in our experience, that the serum chloride of the diabetes insipidus subject rises higher than in the normal in response to a given dose of salt. Third, it is not true that the serum protein of a diabetes insipidus subject shows less dilution than the normal in response to a given dose of salt. In the ex- 
periment of Figure 4 the serum protein was not followed, but in other experiments it has shown a dilution on salt ingestion quite comparable with the normal. Thus, in a pair of experiments on a normal subject and on the diabetes insipidus subject of Figure 4 the serum protein in grams per $100 \mathrm{cc}$. in the normal was 7.82 before the salt dose of 0.25 gram per kilo, 7.961 hour after the dose, 7.884 hours after the dose, 6.9624 hours later, and 7.1048 hours later, while the corresponding figures for the diabetes insipidus subject were $7.12,7.06,6.99,6.64$, and 6.53. Finally, we cannot understand why an increased molecular concentration of the blood should stimulate the kidneys to increased water elimination in the absence of any increase in elimination of solids.

We have found no consistent differences in the blood responses of the diabetes insipidus subject as compared with the normal on ingestion of water or of 'salt, either with or without accompanying pitressin administration. We have not had any cases fail to show an antidiuretic response to pitressin, as Veil says is the case with the hypochloremic type, although we recognize that this does not mean that such cases cannot exist. It is our impression that Veil's hypochloremic cases were not true diabetes insipidus.

Our concept of this condition, as contrasted with that of various of the German workers, follows. Diabetes insipidus is due to a deficiency of the antidiuretic principle secreted by the pars nervosa of the hypophysis and adjacent floor of the third ventricle. This principle acts on the renal tubules rather than on the tissues in general; it enables the tubules to reabsorb water from a hypertonic solution in their lumen. The renal tubules in diabetes insipidus are less sensitive than normally to acute changes in water or salt concentration of the blood. There is no need to assume a disturbance of exchange of water and salt between tissues and blood in this condition; the blood responses to salt and to water ingestion are normal. There is no basis for the division into hyperchloremic and hypochloremic types; one and the same case while on constant diet may show alternately a hyperchloremia and a hypochloremia. True diabetes insipidus can be distinguished from primary or psychic polydipsia by withholding water for 6 to 12 hours; if the urine flow falls to normal and its concentration rises to normal the case is a primary polydipsia. If the polyuria persists, the case is either diabetes insipidus or belongs to a type of renal disease unable to put out a concentrated urine; the latter condition should be recognizable by other appropriate measures. One such measure may be mentioned. If the patient is put on a low salt intake ( 1 to 2 grams daily) (in the absence of gross sweating or diarrhea) he will, if a case of diabetes insipidus, come into chloride equilibrium within 2 to 4 days, without a consistently significant lowering of serum chloride, i.e., he will behave in these respects as does a normal subject. A case of renal disease of the type likely to be confused with diabetes insipidus will, on the other hand, usually show a diminished ability to conserve salt as well as water; he will continue in negative chloride balance and, if the procedure is prolonged, will show a progressive fall in serum chloride.

\section{SUMMARY}

With 4 cases of diabetes insipidus studied, all have failed to show within a few hours an increase in urine flow in response to a large drink of water, when urine flow preceding the drink was below maximal.

Normal subjects show within 2 hours a greatly increased rate of urinary chloride output in response to a dose of 0.25 gram of $\mathrm{NaCl}$ per kilo in 10 per cent solution. Of the 4 cases of diabetes insipidus studied, 3 have failed to show any increase in chloride output within 5 hours while 1 has responded essentially normally. Where a delay in chloride output occurs, the delay is not due to a failure of rise of serum chloride.

Both normal and diabetes insipidus subjects excrete about 40 per cent of the above dose of salt during the first 24 hours, about 40 per cent during the second 24 hours, and the remainder within the next day or two. This is true whether the experiment be done during a period of high or low daily salt intake, provided the subject is able to conserve salt adequately, i.e., to come into salt equilibrium on low salt intake before serum salt is significantly lowered. The only qualification is that a day longer may be required for elimination of the dose on a low as compared with a high daily salt intake. The serum chloride is high for the first day but is practically always down to or below 
normal by the end of 24 hours and thereafter. The maintenance of the high rate of chloride output during the second 24 hours is not satisfactorily explained, although some guesses are proposed.

In neither normal nor diabetes insipidus subjects has 0.15 unit of pitressin per kilo subcutaneously resulted in any consistent increase in rate of urinary chloride output, either with or without a large drink of water; the behavior of the serum chloride is not affected by the pitressin. The antidiuretic action of this dose of pitressin is marked for 4 to 6 hours in both normal and diabetes insipidus subjects; following this it diminishes rapidly and is usually not apparent after 8 hours. The antiduretic action of pitressin in the normal subject is, of course, observed by following the pitressin with a large drink of water.

The rise in serum chloride and in rate of chloride output following a dose of 0.25 gram of $\mathrm{NaCl}$ per kilo in 10 per cent solution is either unaffected or somewhat diminished by a dose of 0.15 unit pitressin per kilo subcutaneously 1 hour previously, in both the normal and the diabetes insipidus subject.

Since the blood changes in all of the procedures carried out have been the same in the normal and in the diabetes insipidus subject, differences in urinary responses may logically be referred to differences in sensitivity of the kidneys, presumably the tubules, to environmental changes. Each of the 4 cases of diabetes insipidus studied has shown kidneys less sensitive than the normal to the fall in plasma molecular concentration brought on by a large drink of water. Three of the 4 cases have shown kidneys less sensitive (within the first few hours) than the normal to the increase in plasma molecular concentration brought on by a large dose of $\mathrm{NaCl}$; one' (the least severe) has shown essentially normal sensitivity in this respect.

It is believed that there is no justification for the division of cases with diabetes insipidus into hyperchloremic-hypochloruric and hypochloremichyperchloruric types, or for the view that the condition is primarily a disturbance of the processes of exchange of water and salt between tissues and blood.
We wish to express our thanks to Dr. A. F. Hartmann for the facilities of the metabolism ward of the St. Louis Children's Hospital in the study of 1 case with diabetes insipidus and 1 normal case.

\section{BIBLIOGRAPHY}

1. Findley, T., Jr., and White, H. L., The response of normal individuals and patients with diabetes insipidus to the ingestion of water. J. Clin. Invest, 1937, 16, 197.

2. Peters, J. P., and Van Slyke, D. D., Quantitative Clinical Chemistry. Vol. II. Methods. Williams and Wilkins Co., Baltimore, 1932, p. 833.

3. Sendroy, J., Jr., Microdetermination of chloride in biological fluids, with solid silver iodate. II. Titrimetric analysis. J. Biol. Chem., 1937, 120, 405.

4. White, H. L., and Findley, T., Jr., Time relations in renal excretion of threshold and no-threshold substances. Am. J. Physiol., 1937, 119, 740.

5. Allen, F. M., and Sherrill, J. W., Diet treatment of diabetes insipidus. J. Metab. Res., 1923, 3, 479.

6. Ambard, L., La sécrétion chlorurée dans le diabéte insipide. Médicine, 1931, 12, 230.

7. Decourt, J., Meyer, L., Audry, M., and Lesourd, R., Diabète insipide. Action du régime déchlorure sur le polyurie. Bull. et mém. soc. méd. d. hôp. de Paris, 1934, 50, 1695.

8. Dreyfus, G., Remarques sur la physiopathologie du diabète insipide. Bull. et mém. soc. méd. d. hôp. de Paris, 1934, 50, 1755.

9. Lichtwitz, L., Die Konzentrationsarbeit der Niere. Arch. f. exper. Path. u. Pharmakol., 1911, 65, 128.

10. Pellegrini, G., Contributo allo studio del diabeta insipido. 1. I rapporti fra il ricambio idrico intermedio e la poliuria. Clin. med. ital., 1931, 62, 899.

11. Rabinowitch, I. M., Metabolic studies on a case of diabetes insipidus. Arch. Int. Med., 1921, 28, 355.

12. Rosenbloom, J., and Price, H. T., Metabolism study of a case of diabetes insipidus. Am. J. Dis. Child., 1916, 12, 53.

13. Veil, W. H., Uber intermediäre Vorgänge beim Diabetes insipidus und ihre Bedeutung für die Kenntnis vom Wesen dieses Leidens. Biochem. Ztschr., 1918, 91, 317.

14. Veil, W. H., Uber die Bedeutung intermediärer Veränderungen im Chlorstoffwechsel beim Normalen und beim Nierenkranken. Biochem. Ztschr., 1918, 91, 267.

15. Marx, H., Der Wasserhaushalt des gesunden und kranken Menschen. Springer, Berlin, 1935, p. 267.

16. Veil, W. H., Physiologie und Pathologie des Wasserhaushaltes. Ergebn. d. inn. Med. u. Kinderh., 1923, 23, 648. 